\title{
MAP2K1 Gene Amplification
}

National Cancer Institute

\section{Source}

National Cancer Institute. MAP2K1 Gene Amplification. NCI Thesaurus. Code C153253.

A molecular genetic abnormality indicating the presence of multiple copies of the MAP2K1 gene. 